\title{
Manchester Protocol at a school hospital emergency service
}

\author{
Protocolo de Manchester em pronto atendimento de hospital escola
}

Mayara Raphaela Morais Rezende ${ }^{1}$, Flavia Falci Ercole ${ }^{1}$, Selme Silqueira de Mattos ${ }^{1}$, Miguir Terezinha Vieccelli Donoso $^{1}$

Objective: to analyze the flow of directing patients triaged by the Manchester Protocol in the emergency service of a school hospital. Methods: a retrospective, descriptive and documentary study using triage records. The sample was composed of 364 records that were analyzed through descriptive statistics, using simple and relative frequencies and measures of central tendency. Results: the most frequent complaints were those related to the musculoskeletal system (26.1\%) and gastrointestinal system (15.1\%). The highest demand was for general practice (47.5\%). The most frequent risk classification was green (78.3\%). Most of the individuals studied received hospital discharge (92.6\%). Conclusion: the results suggest that urgency and emergency units are being sought to solve problems that could be solved by primary care units.

Descriptors: Triage; Emergencies; Nurses.

Objetivo: analisar o fluxo de direcionamento de pacientes triados pelo Protocolo de Manchester em pronto atendimento de hospital escola. Métodos: estudo retrospectivo, descritivo e documental, utilizando-se fichas referentes às triagens. Amostra composta de 364 fichas que foram analisadas por meio de estatística descritiva, utilizando-se frequências simples e relativa e medidas de tendência central. Resultados: as queixas mais frequentes dos pacientes atendidos foram as relacionadas ao sistema musculoesquelético $(26,1 \%)$ e ao sistema gastrointestinal $(15,1 \%)$. A maior demanda foi para clínica geral $(47,5 \%)$. A classificação de risco mais frequente foi verde (78,3\%). A maioria dos indivíduos estudados teve alta hospitalar (92,6\%). Conclusão: os resultados sugerem que unidades de urgência e emergência estão sendo procuradas para solucionar problemas que poderiam ser resolvidos pelas unidades de atenção primária.

Descritores: Triagem; Emergência; Enfermeiras e Enfermeiros.

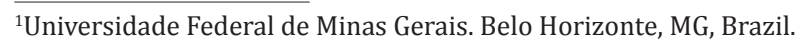




\section{Introduction}

Emergency service units are spaces destined for the care of people with acute or exacerbated health conditions that require rapid care, with or without risk of death, but whose health problems inspire the need for immediate or non-immediate care ${ }^{(1)}$.

In these units, emergency and urgency interventions are carried out. These would include emergencies regarding medical conclusions of worsening of health conditions that entail intense suffering or imminent risk of death, thereby requiring immediate medical treatment. Urgency being an unforeseen occurrence of health aggravation with or without potential risk to life, where the patient needs immediate medical assistance ${ }^{(2)}$.

The assessment of what is an emergency or urgency is completed upon the triage moment, this when the patient's condition, potential risks, pain and suffering are analyzed. In Minas Gerais, Brazil, the State Department of Health chose to standardize care by importing and implementing the Manchester Protocol at the entranceway of health services ${ }^{(3)}$. This allows for identifying and prioritizing the most severe cases. The more severe the patient's situation, the faster they will be attended, regardless of their order of arrival; remembering that when it comes to urgency and emergency, time is life.

The Manchester Protocol encompasses five situations: Emergency/Immediate (red): patient needs immediate care since there is risk of death, maximum waiting time of 0 minutes; Very urgent (orange): patient needs fast care, maximum waiting time of 10 minutes; Urgent (yellow): patient needs care, but it is not considered an emergency and can wait for the most severe cases, maximum waiting time of 60 minutes; Not very urgent/standard (green): the least serious case of patients who need medical attention, but could be assisted in the outpatient clinic, maximum waiting time of 120 minutes; Nonurgent (blue): a case of less complex cases with no connection to recent problems, it should preferably be clinically attended to in a doctor's office, maximum waiting time of 240 minutes $^{(4)}$.

Despite the proposal of the Unified Health System for hierarchical and regionalized care, the emergency services of hospitals of medium and high complexity on a daily basis face long lines for in attending to patients. A study conducted in São Paulo, Brazil, sought to describe the paths taken by users to access medium complexity services from the perspective of managers and users. Medium complexity was identified as the "bottleneck" of the Unified Health System and one of the main obstacles to achieving comprehensiveness. A large variety of complaints that motivated people to seek the emergency service were also observed ${ }^{(5)}$.

According to the nursing coordinator of an emergency service of a large school hospital in Belo Horizonte, Brazil, the hospital attends an average of 6,700 patients per month. This is a significant number, however the data regarding the services are not systematized and analyzed. The same coordination point out that this service is not computerized, which makes it difficult to know the directional flow of the patients attending it, as well as the causes of the demand for the service, the type of population served and the most common complaints, thus hindering progress in terms of referrals and care planning.

It should be noted that the Manchester Protocol is a recent issue, and studies that address its use in emergency services, specifically in Brazil, are still incipient. Knowledge about the clinical demand of urgency and emergency units that make use of this protocol may contribute to organizing the care network of the municipality in which it is inserted, as it will bring relevant information for the action planning of pacts with lower and higher complexity health services for the referral of the necessary $\operatorname{cases}^{(6)}$.

Thus, this study aimed at analyzing the directional flow of patients triaged by the Manchester Protocol in an emergency service of a hospital school. 


\section{Methods}

This is a retrospective, descriptive and documentary study, conducted in the emergency service of a hospital school of a Brazilian capital. This hospital specifically attends patients with clinical problems, and is not a reference for trauma victims.

Data regarding the triaged patients were collected through information contained in the reports relating to the visits which occurred in the unit in the year 2014, at all three shifts of the day (morning, afternoon and night). A data collection instrument developed by the researchers with sociodemographic and clinical variables, as well as those variables related to triage using the Manchester Protocol.

The sample size was calculated using the Open-Epi program, version 3, open source calculator, using the formula $n=\left[D_{E F F} * N p(1-p)\right] /[(d 2 / Z 21$ $\left.-\alpha / 2^{*}(\mathrm{~N}-1)+p^{*}(1-\mathrm{p})\right]$. Considering an average population of 6700 patients triaged monthly, the proportion expected for the events studied was $50.0 \%$, with an alpha error of 5.0\% and Design Effect (DEFF) of 1 . The Confidence Interval (CI) considered was 95.0\%. The estimated sample size was 364 triaged patient records.

The data collected were input into a Microsoft Excel Program version 2013 database for data organization and subsequently exported to the Statistical Package for the Social Sciences version 19 statistical program for data analysis.

The variables used were: a) age in years (continuous quantitative variable); b) gender (nominal and categorical variables); c) main complaint by systems (categorical variable); d) referral clinic (categorical variable); e) protocol classification according to color (categorical variable) and f) outcome (categorical variable). The age variable was later categorized into intervals for analysis.

Data analysis was performed through descriptive analysis. Simple and relative frequency calculations were used, as well as measures of central tendency (mean) and measure of variability (standard deviation) in order to characterize the attended population. We emphasize that the data of the studied variables have a normal distribution, which justifies the use of the mean for description of continuous variables.

The study respected the formal requirements contained in national and international regulatory norms/guidelines for research involving human subjects.

\section{Results}

A total of 364 patient records were triaged in the emergency service of the hospital under study. The mean age was 44 years (standard deviation = 19.7). The highest percentage of patients was in the 20-30 age group (23.9\%; 95\% CI: 19.49-2.30). The majority of subjects were female $(60.0 \%, 95 \% \mathrm{CI}=$ 54.55-64.67) (Table 1).

Table 1 - Demographic characteristics of patients triaged in the emergency service of a school hospital of a Brazilian capital

\begin{tabular}{lcc}
\hline Variables & $\mathbf{n}(\%)$ & Confidence Interval 95\% \\
\hline Age (years) & & $0.21-1.31$ \\
$<12$ & $2(0.5)$ & $4.48-9.80$ \\
$12-19$ & $26(7.1)$ & $19.49-28.30$ \\
$20-30$ & $87(23.9)$ & $13.40-21.21$ \\
$31-40$ & $63(17.3)$ & $14.15-22.10$ \\
$41-50$ & $66(18.1)$ & $7.28-13.59$ \\
$51-60$ & $38(10.4)$ & $6.57-12.65$ \\
$61-70$ & $35(9.6)$ & $6.10-12.02$ \\
$71-80$ & $33(9.0)$ & $1.45-5.13$ \\
$81-89$ & $12(3.3)$ & $0.21-1.31$ \\
$\geq 90$ & $2(0.5)$ & \\
Gender & & $54.55-64.67$ \\
Female & $217(59.6)$ & $35.32-45.44$ \\
Male & $147(40.3)$ & \\
\hline
\end{tabular}


The most frequent complaints of the patients at the time of screening were those related to musculoskeletal system (26.1\%; CI 95\%: 21.6-30.63) and gastrointestinal system (15.1\%; CI 95\%: 11.41 18.81), followed by complaints related to the upper respiratory system, such as nasal cavity, paranasal sinuses, nasopharynx and oropharynx $(11.0 \%, 95 \%$ CI: 7.77-14.21). These data are shown in Table 2.

Table 2 - Classification of the complaints of patients triaged in the emergency service of a school hospital of a Brazilian capital

\begin{tabular}{lcc}
\hline Main complaints & $\mathbf{n ( \% )}$ & $\begin{array}{c}\text { Confidence } \\
\text { Interval 95\% }\end{array}$ \\
\hline System & & \\
Gastrointestinal & $55(15.1)$ & $11.41-18.81$ \\
Respiratory & $20(5.5)$ & $3.14-7.85$ \\
Genitourinary & $19(5.2)$ & $2.92-7.52$ \\
Cardiovascular & $16(4.4)$ & $2.28-6.51$ \\
Auditory & $14(3.8)$ & $1.86-5.83$ \\
Nervous & $11(3.0)$ & $1.26-4.79$ \\
Endocrine system & $4(1.1)$ & $0.02-2.17$ \\
Ocular & $2(0.55)$ & $0.00-1.31$ \\
Nasal cavity, paranasal sinuses, naso- & $40(11.0)$ & $7.77-14.21$ \\
pharynx, Oropharynx & & \\
Locomotive system & $95(26.1)$ & $21.6-30.63$ \\
Pain after trauma & $29(7.9)$ & $5.17-10.76$ \\
Fever & $5(1.37)$ & $0.17-2.57$ \\
Skin (rash, pruritus, wound, incision) & $18(4.9)$ & $2.71-7.18$ \\
Other & $36(9.8)$ & $6.81-12.97$ \\
\hline & & \\
\hline
\end{tabular}

In relation to the clinic for which the patient was referred, general practice was the medical specialty with the highest demand (47.5\%, 95\% CI: 42.37 $52.68)$, followed by the orthopedic clinic (20.6\%; $95 \%$ CI: 16.42 - 24.77) and general surgery (15.7\%; 95\% CI: 11.90 - 19.41).

According to the Manchester Protocol, the most frequent risk classification color was green $(78.3 \%$; 95\% CI: $74.04-82.55)$, followed by yellow (18.1\%; 95\% CI: 14.15 - 22.10).
Most of the patients studied received hospital discharge from the emergency service $(92.6 \%, 95 \%$ CI: 89.87 - 95.28), while $6.6 \%$ of them remained hospitalized (95\% CI: 4.03 - 9.15) and 0.8\% (95\% CI: $0.10-1.75)$ evolved to death during hospitalization. Table 3 illustrates this data.

Table 3 - Characteristics of the care provided to patients triaged in the emergency service of a school hospital of a Brazilian capital

\begin{tabular}{lcc}
\hline Variables & $\mathbf{n}(\%)$ & Confidence Interval 95\% \\
\hline Specialization & & \\
General Practitioner & $173(47.5)$ & $42.37-52.68$ \\
Orthopedic Surgeon & $75(20.6)$ & $16.42-24.77$ \\
General Surgeon & $57(15.7)$ & $11.90-19.41$ \\
Otolaryngology & $53(14.6)$ & $10.91-18.20$ \\
Emergency specialist & $6(1.6)$ & $0.33-2.96$ \\
Classification & & \\
Green & $285(78.3)$ & $74.04-82.55$ \\
Yellow & $66(18.1)$ & $14.15-22.10$ \\
Orange & $9(2.47)$ & $0.86-4.07$ \\
Red & $4(1.1)$ & $0.02-2.17$ \\
Outcome & & $89.87-95.28$ \\
Hospital discharge & $337(92.6)$ & $4.03-9.15$ \\
Hospitalization & $24(6.6)$ & $0.10-1.75$ \\
Death & $3(0.8)$ & \\
\hline
\end{tabular}

\section{Discussion}

Regarding age, the mean value found in this study was similar to that of a study carried out in a reference emergency unit of a large teaching hospital, with an average age of 41.6 years $^{(7)}$. It is a sample composed mostly of adults being of a productive age.

The majority of users were females, unlike another study ${ }^{(8)}$ performed in another reference emergency service in Belo Horizonte, Brazil, whose users were predominantly males. However, this sector addressed clinical and traumatic conditions, unlike the emergency service of this study, exclusively for clinical care. Females are less exposed to trauma ${ }^{(9)}$.

The most frequent complaints were related to the musculoskeletal system. This can be explained by 
a number of factors, such as overweight and obesity which contribute to locomotor disorders ${ }^{(10)}$. In Brazil, the number of overweight and obese individuals is significant ${ }^{(11)}$. Other factors, such as a sedentary lifestyle are related to injuries/conditions such as low backpain ${ }^{(12)}$, also highlighting that the number of people practicing physical activity in Brazil is still small. In addition, the older adult population has increased ${ }^{(13)}$, and the literature ${ }^{(14)}$ points to physiological changes that occur in the musculoskeletal system due to aging, such as a loss of muscle mass, loss of body balance, decreased bone mass and osteoarthrosis.

On the other hand, gastrointestinal symptoms which were the second reason for seeking the emergency service under study were also frequent findings in an integrative review carried out on emergency service users ${ }^{(15)}$. These may be related to functional or psychological factors ${ }^{(16)}$. It is believed that the fast pace of life in the present day can contribute to the appearance of these aggravations.

The complaints related to the upper airways, herein referred to as the upper respiratory system (nasal cavity, paranasal sinuses, nasopharynx, oropharynx) were the third cause of demand for this emergency service. Complaints related to the upper airways also constituted the second cause of demand in a study carried out in a public emergency room in the State of São Paulo, Brazil. The search for care occurred to meet needs, whether acute or not, which were brining limitations and discomfort to users ${ }^{(17)}$.

In relation to the most demanded referral clinics of the patients, general practice constituted almost half of the sample. This result is most likely related to the hospital model under study, since this is not a reference for trauma. Thus, clinical visits were more frequent.

The green rating represented the majority of the services offered. This data corroborates a study performed in an emergency service unit in the interior of Minas Gerais, Brazil, where $61.0 \%$ of the patients triaged were classified as green, emphasizing the "hospital-centric" model, in which the emergency units are sought to solve problems that could be solved by primary care units. They reinforce the need to raise awareness among the population about the government's decentralization strategies of urgency and emergency care networks ${ }^{(6)}$.

Regarding outcome, the vast majority of triaged patients received hospital discharge, a fact that deserves further reflection. A study carried out in a Brazilian emergency service considers that the causes that lead to increased demand in urgency and emergency services reflect social, epidemiological, and cultural issues, as well as aspects related to the organization of the health system ${ }^{(18)}$. In Brazil, it can be observed that most of the cases in the emergency services are not acute but rather chronic cases; in other words, elective services that are mischaracterized as emergency services. Emergency services in Brazil are fast and decisive emergency care locations, however, they might be serving as a gateway for outpatient cases, which could be served by the basic health network ${ }^{(19)}$.

This study presented as a limitation the fact that some important variables were not obtained, as the service does not record data such as duration of care and outcome occurrence.

\section{Conclusion}

The emergency service under study portrayed the reality of several emergency and primary care service units of the country, since the green classification constituted a large majority of the services performed. In analogy, these are care services that could be performed in primary care units. The "hospital-centric" model, mentioned in the discussion of this study seems to be (deeply) rooted in the population's health habits. The directional flow of patients triaged by the Manchester Protocol pointed to a vast majority of hospital discharges. This deserves further reflection since many 'not-lessserious' yet less urgent care cases could be resolved at the outpatient level. 


\section{Collaborations}

Rezende MRM, Ercole FF, Mattos SS and Donoso MTV contributed to project design, analysis and interpretation of data, writing (of the article), critical review of intellectual content and final approval of the version to be published.

\section{References}

1. Ministério da Saúde (BR). Portaria n. 342 de 04 de março de 2013: aprova as diretrizes para implantação do Componente Unidade de Pronto Atendimento (UPA 24h) em conformidade com a Política Nacional de Atenção às Urgências. Brasília: Ministério da Saúde; 2013.

2. Ministério da Saúde (BR). Portaria n ${ }^{\circ} 354$ de 10 de março de 2014: aprova a proposta de Projeto de Resolução "Boas Práticas para Organização e Funcionamento de Serviços de Urgência e Emergência". Brasília: Ministério da Saúde; 2014.

3. Souza CC, Toledo AD, Tadeu LFR, Chianca TCM. Risk Classification in an Emergency Room: Agreement Level Between a Brazilian Institutional and the Manchester Protocol. Rev Latino-Am Enfermagem. 2011; 19(1):26-33.

4. Silva AP, Diniz AS, Araújo FA, Souza CC. Presença da queixa de dor em pacientes classificados segundo o Protocolo de Manchester. Rev Enferm Cent Oeste Min. 2013; 3(1):507-17.

5. Spedo SM, Pinto NRS, Tanaka OY. O difícil acesso a serviços de média complexidade do SUS: o caso da cidade de São Paulo, Brasil. Physis. 2010; 20(3):953-72.

6. Diniz AS, Silva AP, Souza CC, Chianca TCM. Demanda clínica de uma unidade de pronto atendimento, segundo o Protocolo de Manchester. Rev Eletr Enferm [Internet]. 2014 [citado 5 mar. 2015]; 16(2):312-20. Disponível em: http:// revistas.ufg.br/fen/article/view/21700/16967
7. Oliveira GN, Silva MFN, Araujo IEM, CarvalhoFilho MA. Profile of the Population Cared for in a Referral Emergency Unit. Rev Latino-Am Enfermagem. 2011; 19(3):548-56.

8. Pinto Junior D, Salgado PO, Chianca TCM. Predictive validity of the Manchester Triage System: evaluation of outcomes of patients admitted to an emergency department. Rev Latino-Am Enfermagem. 2012; 20(6):1041-7.

9. Pinheiro AI, Almeida FM, Barbosa IV, Mesquita Melo E, Studart RMB, Carvalho ZMF. Principais causas associadas ao traumatismo cranioencefálico em idosos. Enferm Glob [Internet]. 2011 [citado 2016 jul 13]; 10(22):1-11. Disponível em: http://scielo. isciii.es/pdf/eg/v10n22/pt_clinica4.pdf

10. Abreu LC. Condições relacionadas à obesidade secundária na interface do crescimento $\mathrm{e}$ desenvolvimento [editorial]. Rev Bras Cresc Desenv Hum. 2011; 21(1):7-10.

11. Conde WL, Borges C. O risco de incidência e persistência da obesidade entre adultos Brasileiros segundo seu estado nutricional ao final da adolescência. Rev Bras Epidemiol. 2011; 14(suppl.1):71-9.

12. Barros SS, Angelo RCO, Uchoa EPBL. Lombalgia ocupacional e a postura sentada. Rev Dor. 2011; 12(3):226-30.

13. Santos SSC, Gautério DP, Vidal DAS, Rosa BM, Zortea B, Urquia BS. (In)dependence of elderly people at their home in performing basic activities of daily living. Rev Rene. 2013; 14(3):579-87.

14. Araújo APS, Bertolini SMMG, Martins Junior J. Alterações morfofisiológicas decorrentes do processo de envelhecimento do sistema musculoesquelético e suas consequências para o organismo humano. Perspep Online Biol Saúde [Internet]. 2014 [citado 2016 out. 20]; 12(4):22-34. Disponível em: http://www. seer.perspectivasonline.com.br/index.php/ biologicas_e_saude/article/view/42/409 
15. Acosta AM, Lima MADS. Características de usuários frequentes de serviços de urgência: revisão integrativa. Rev Eletr Enferm [Internet]. 2013 [citado 2016 out. 20]; 15(2):564-73. Disponível em: www.fen.ufg.br/fen_revista/v15/ n2/pdf/v15n2a31.pdf

16. Oliveira AF, Carvalho JR, Costa MSF, Lobato LCP, Silva RS, Schramm JMA. Estimativa da prevalência e da mortalidade por complicações da úlcera péptica, Brasil, 2008: uma proposta metodológica. Epidemiol Serv Saúde. 2015; 24(1):145-54.

17. Olivati FN, Brandão GAM, Vazquez FL, Paranhos LR, Pereira AC. Perfil da demanda de um prontosocorro em um município do interior do estado de São Paulo. Rev Faculd Odontol [Internet]. 2010 [citado 2016 out.20];15(3):245-50. Disponívelem: http://pepsic.bvsalud.org/scielo.php?script=sci_ arttext\&pid=S1516-36872009000100008
18. Coelho MF, Chaves LDP, Anselmi ML, Hayashida M, Santos CB. Analysis of the Organizational Aspects of a Clinical Emergency Department: A Study in a General Hospital in Ribeirao Preto, SP, Brazil. Rev Latino-Am Enfermagem. 2010; 18(4):770-7.

19. Oliveira SN, Ramos BJ, Piazza M, Prado ML, Reibnitz KS, Souza AC. Unidade de pronto atendimento - UPA 24h: percepção da enfermagem. Texto Contexto Enferm. 2015; 24(1):238-44. 